\title{
Ensilability and chemical composition of silages made with different mixtures of noni (Morinda citrifolia $L$.)
}

\author{
Ensilabilidad y composición química de ensilajes elaborados con diferentes \\ mezclas de noni (Morinda citrifolia L.) \\ Yoandris Pascual Sánchez ${ }^{1}$ \\ Cesar Betancur-Hurtado ${ }^{2}$ \\ Aroldo Botello-León ${ }^{3}$ \\ Kirenia Pérez-Corría ${ }^{4}$ \\ Cristina Ruiz-Corrales ${ }^{5}$ \\ Yordan Martínez-Aguilar ${ }^{6}$
}

Fecha de recepción: 12 de octubre de 2018

Fecha de aprobación: 21 de diciembre de 2018

\begin{abstract}
The ensilability and chemical composition of silages made with different proportions (100:0; $90: 10 ; 80: 20 ; 70: 30 ; 60: 40$ and 50:50\%) of foliage (fresh and pre-wilted) and noni fruit (fresh) was evaluated. Some fermentative patterns of the original forages and the chemical content of the silages were determined. Correlations between the parameters of quality, chemical composition and the fruit levels in the mixture were made and adjusted the same one to polynomial equations. A higher inclusion of fruits with both fresh and pre-wilted foliage of noni decreases the $\mathrm{pH}$ and $\mathrm{NH} 3-\mathrm{N} \mathrm{Nt}{ }^{1}$ in the silage. In addition, the increase in the level of fruit increased the concentration of water soluble carbohydrates (WSC) and the ratio of WSC/PC. Moreover, the pre-wilted foliage increased the dry matter (DM) content and its combination with fruit levels between 30 to $40 \%$ decreased the fibrous compounds and crude protein (CP) concentration in the silage. According to a cubic model used, the pre-wilted foliage and fruit proportions showed a higher $\mathrm{R}^{2}$ for DM, neutral detergent fiber (NDF), acid detergent fiber (ADF), acid detergent-lignin (ADL) and cellulose, while CP and hemicelluloses were higher in the fresh plant material. The results showed that the pre-withered process (foliage) and inclusion levels of 30 and $40 \%$ of fruits in the mixture improved the quality of the silage intended for animals.
\end{abstract}

Keywords: fermentation; foliage; food preservation; fruit; noni; wilted.

\footnotetext{
${ }^{1}$ M. Sc. Universidad de Granma (Granma, Cuba). ypascuals@udg.co.cu. ORCID: 0000-0003-2270-5012.

${ }^{2}$ M. Sc. Universidad de Córdoba (Córdoba-Montería, Colombia). cbetancour@correo.unicordoba.edu.co. ORCID: $\underline{0000-}$ 0001-7617-2202.

${ }^{3}$ Ph. D. Universidad Técnica "Luis Vargas Torres" (Esmeraldas, Ecuador). aroldo.botello@utelvt.edu.ec. ORCID: 00000001-6709-2104.

4 M. Sc. Universidad Técnica "Luis Vargas Torres" (Esmeraldas, Ecuador). kirenia.perez@utelvt.edu.ec. ORCID: $\underline{0000-}$ 0002-0216-328X.

${ }^{5}$ Servicio Nacional de Aprendizaje - SENA (Montería, Colombia). ORCID: 0000-0002-5023-0061.

${ }^{6}$ Ph.D. Institute of Subtropical Agriculture, Chinese Academy of Sciences (Changsha-Hunan, China). ORCID: $\underline{0000-}$ 0003-2167-4904.
}

Ciencia y Agricultura (Cien. Agri.) Vol. 16 (1). L-ISSN 0122-8420. eISSN 2539-0899.

Enero-Abril 2019, pp. 3-16. Tunja (Boyacá) - Colombia. DOI:

https://doi.org/10.19053/01228420.v16.n1.2019.8802 


\section{Resumen}

Se evaluó la ensilabilidad y la composición química de ensilajes elaborados con diferentes proporciones (100: 0; 90:10; 80:20; 70:30; 60:40 y 50:50\%) de follaje (fresco y presecado) y la fruta de noni (fresca). Se determinaron algunos patrones de fermentación de los forrajes originales y el contenido químico de los ensilajes. Se hicieron correlaciones entre los parámetros de calidad, la composición química y los niveles de fruta en la mezcla y se ajustaron a ecuaciones polinomiales. Una mayor inclusión de frutas con follaje fresco y pre-secado de noni, disminuyó el pH y el NH3-N $\mathrm{Nt}^{-1}$ en el ensilaje. Además, en incremento en el nivel de fruta aumentó la concentración de carbohidratos solubles en agua (CSA) y la relación de CSA/PB. También, el follaje pre-secado aumentó el contenido de materia seca (MS) y su combinación con niveles de fruta entre 30 a 40\%, disminuyó los compuestos fibrosos y la concentración de proteína bruta (PB) en el ensilaje. Según un modelo cúbico utilizado, las proporciones de follaje y frutos previamente presecado, mostraron un $R^{2}$ mayor para MS, fibra detergente neutra (FDN), fibra detergente ácida (FDA), lignina ácido detergente (LAD) y celulosa, mientras que PB y hemicelulosa, fueron superiores en el material vegetal fresco. Los resultados mostraron que el proceso pre-secado (follaje) y los niveles de inclusión de 30 y $40 \%$ de las frutas en la mezcla, mejoraron la calidad del ensilaje destinado a los animales.

Palabras clave: conservación de alimento; fermentación; follaje; fruta; secado; noni.

\section{Para citar este artículo:}

Sánchez, Y. P., Betancur-Hurtado, C., Botello-León, A., Pérez-Corría, K., Ruiz-Corrales, C., \& Martínez-Aguilar, Y. (2019). Ensilability and chemical composition of silages made with different mixtures of noni (Morinda citrifolia L.). Ciencia y Agricultura, 16(1), 3-16. DOI: https://doi.org/10.19053/01228420.v16.n1.2019.8802.

Esta obra está bajo licencia internacional Creative Commons Reconocimiento 4.0

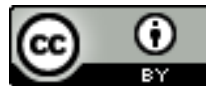




\section{Introduction}

The production of non-ruminant animals in the tropical area is limited by several factors; the most important of these factors is the obtaining of necessary nutrients to supply the nutritional requirements of these animals; in many cases conventional feeds are used, which contain large percentages of cereals and protein sources such as soybeans and fishmeal (Santana et al., 2015). The high costs of some conventional raw ingredients by the boom in the production of agrofuel and other extrinsic and intrinsic factors of the market has a direct impact on animal production, mainly in this geographical area (Martínez et al., 2015).

On the other hand, trees and bush have a great diversity and adaptation to various ecosystems, these feeds are considered to be technically, biologically and economically viable alternatives to animal feeding (Vandermeulen et al., 2018). Noni (Morinda citrifolia L.) is a perennial plant, native to Southeast Asia, it grows in tropical and subtropical regions, it is identified by its large leaves, straight stem and yellow fruits (Sang et al., 2001). This plant has been widely studied by their medicinal properties, is considered as one of the main sources of biologically active compounds (Arunachalam et al., 2018). The fruit are rich sources of watersoluble polysaccharides such as fucose, xylose, mannose, galactose and fructose, minerals such as potassium, sulfur, calcium and phosphorus and amino acids such as aspartic acid, glutamic acid and isoleucine (Potterat et al., 2007). However, as feedstuff, few researches have been done in animal production systems (Sakarkar \& Deshmukh, 2011; Ali et al., 2016).

Although this tree offers big kindness for sustainable animal production systems and can also be well adapted to different climatic conditions (Rivera et al., 2012). There are still some limitations for use in animal production systems, such as incomplete characterization of their nutrient contents and lack of knowledge of the effect of noni on digestive and metabolic processes. Therefore, it is necessary to look for technological alternatives that could allow diminishing the antinutritional factors and achieving a better nutritive value.

The silage is one of the main technological processes for the preservation of animal feeds, through a fermentative method in the absence of air (Canibe \& 
Jensen, 2011; Ke et al., 2015; Kung et al., 2018), which propitiates positive nutritional changes and allows an easier and cheaper feeding (Amer et al., 2012; Borreani et al., 2018; Grant \& Ferraretto, 2018). As a result, the objective of this work was to determine the ensilability and chemical composition of silages made with different proportions (100:0; 90:10; 80:20; 70:30; $60: 40$ and 50:50\%) of foliage (fresh and pre-wilted) and noni fruit (fresh).

\section{Materials and methods}

The foliage and noni fruits were harvested in May/2016 the experimental areas at the Study Center of Animal Production at the University of Granma, Bayamo, Cuba, characterized by a flat topography and brown soil with carbonate (Hernández et al., 1991). The annual rainfall is $1218 \mathrm{~mm}$ and the annual average temperature is $25.8{ }^{\circ} \mathrm{C}$. During the growth of the plants, irrigation and fertilizer were not applied.

Foliage was collected by hand, formed by leaves and young stems of 120 days of regrowth, as well as, fruits individually from the trees were selected. For the harvest of fruit, their maturation state (yellow pale color and firmness from very hard to fairly hard) was considered (Rosalizan et al., 2010).

Raw materials before ensiling were homogenized at $1 \mathrm{~mm}$ in laboratory Cullison silos. The foliage for 3 hours with a density of $15 \mathrm{~kg} \mathrm{~m}^{-2}$ was pre-wilted (Santana et al., 2010). Raw materials before ensiling in the laboratory were homogenized to remove all the air and assure a correct compaction density. The silos in the absence of light at room temperature $\left(28 \pm 3^{\circ} \mathrm{C}\right)$ and hermetically covered were placed for 21 days. The silages made with different proportions (100:0; 90:10; $80: 20 ; 70: 30 ; 60: 40$ and 50:50\%) of foliage (fresh and pre-wilted) and noni fruit (fresh). 


\section{A. Chemical analysis}

In order to determine ensilability, $50 \mathrm{~g}$ samples from each experimental variant was taken and $200 \mathrm{ml}$ of distilled water was added. Then, samples into ambient temperature for 48 hours were incubated and $\mathrm{pH}$ quantifications at $0 ; 14 ; 18 ; 22$; 26; 38 and 48 hours post incubation was done (Pieper et al., 2017). Also, water soluble carbohydrates (WSC) contents was determined in fruit (fresh) and foliage (fresh and wilted) samples of according to Wiseman and Irvin (Wiseman \& Irvin, 1957).

After 21 days of ensiling and immediately at the opening of the silos, samples for determination of $\mathrm{pH}$, ammonia nitrogen/total nitrogen ratio $\left(\mathrm{NH}_{3}-\mathrm{N} \mathrm{Nt}^{-1}\right)$ and proximate chemical analysis were taken. Also, $30 \mathrm{~g}$ fresh silages in $270 \mathrm{ml}$ of distilled water in a blender was stirred (AKA-DDR, T03259, Germany) for 2 min, filtrated through cheese cloth, acidified with $2 \%$ of orthophosphoric acid $(\mathrm{v} / \mathrm{v})$ and stored at $-5{ }^{\circ} \mathrm{C}$. In this silage extract, $\mathrm{pH}$ (PHSJ-4A, China) and $\mathrm{NH}_{3}-\mathrm{N} \mathrm{Nt}^{-1}$ before acidification were measured, this last according to Conway (1947).

Samples for proximate analysis by quintupled were analyzed. Dry matter (DM) and crude protein (CP) were determined according to AOAC (2011). The neutral detergent fiber (NDF), acid detergent fiber (ADF), acid detergent-lignin (ADL), cellulose, and hemicellulose were determined according to the method of Van Soest et al. (1991). The DM of the silages was carried out according to the method proposed by Weissbach \& Berg (1977).

\section{B. Statistical analysis}

A general linear means (GLM) model was applied. An analysis of factorial ANOVA, correlations and regressions to investigate the effects of treatments on the fermentative process parameters and chemical composition was carried and 
Duncan's test was applied to determine mean differences according to the statistical software SPSS version 22.0.

To establish the functional relationship between fruit proportions versus the fermentative process parameters and nutrition composition, the equations (linear, quadratic and cubic) were analyzed and the descending method was used. In order to select the best-fitted equation, it was considered the values of $R^{2}$, significance level, standard error of estimate, the significant contribution of the terms of the equation and low indetermination coefficient $\left(1-R^{2}\right)$.

\section{Results}

Figure 1 shows the $\mathrm{pH}$ during incubation of the mixtures made with fresh and foliage pre-wilted and different levels of fresh fruit. The higher inclusion of fruit provoked a decrease of the $\mathrm{pH}$ both in fresh and foliage pre-wilted, although being more evident in the first case. Apparently, stability is achieved after 22 hours of incubation (Figure 1). The lowest $\mathrm{pH}$ values were found at 48 hours between 3.9 and 4.1 for fresh materials and between 4.4 and 4.2 in the pre-wilted foliage at the same period (Figure 1).

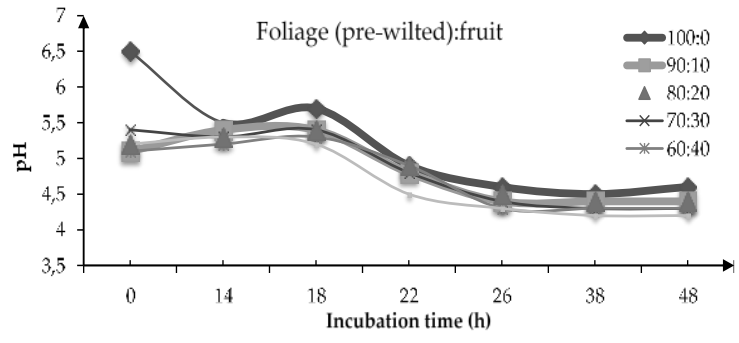

(a)

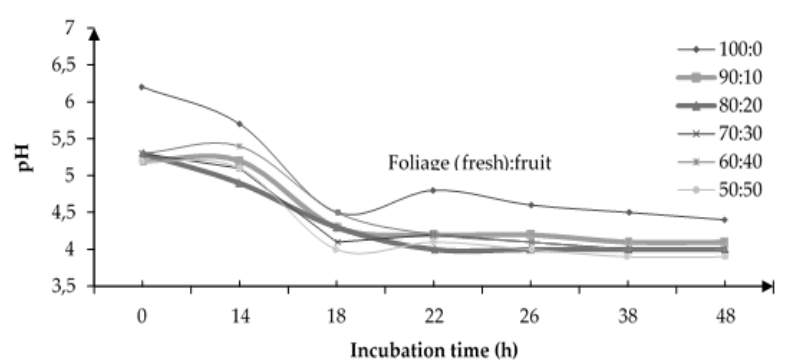

(b)

Fig. 1. Changes in $\mathrm{pH}$ during incubation of the mixture made with different mixtures of noni (Morinda citrifolia L.) pre-wilted (a) and fresh (b). 
A comparison between fresh foliage and pre-wilted foliage with fruit levels for $\mathrm{pH}$ and NH3-N results during incubation are shown in the Figure 2. Under the same fruit inclusion levels, the pre-wilted foliage increased the $\mathrm{pH}$ and decreased the $\mathrm{NH} 3-\mathrm{N}$ concentration (Figure 2).
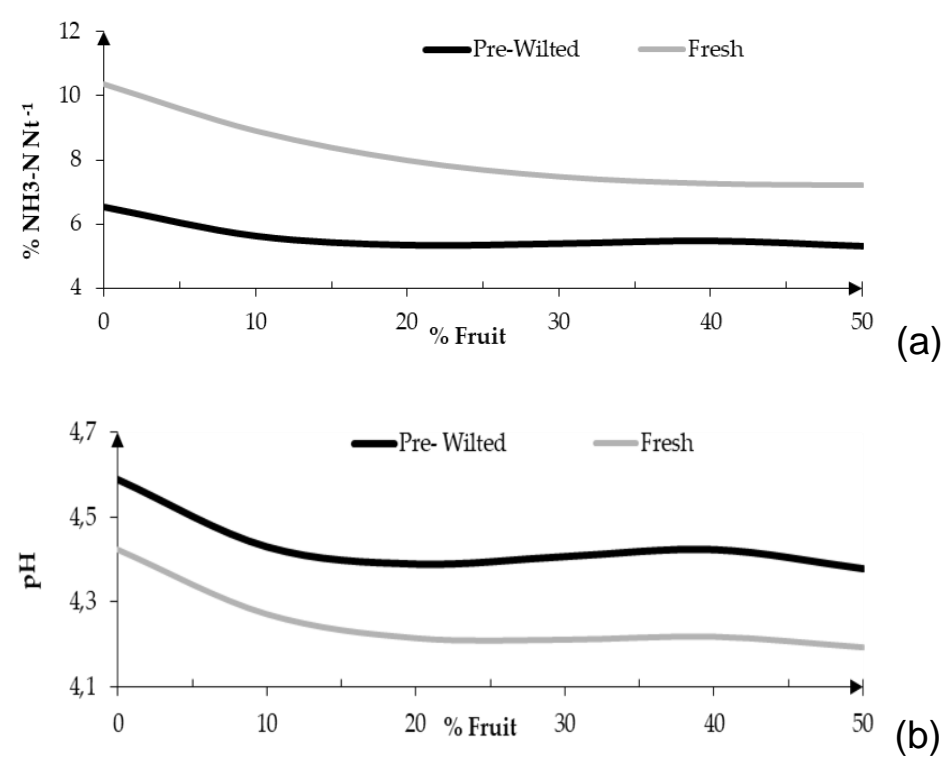

Fig. 2. $\mathrm{pH}$ (a) and $\mathrm{NH}_{3}-\mathrm{Nt}^{-1}$ (b) during incubation of the mixture made with different mixtures of noni (Morinda citrifolia L.).

The pre-wilted foliage showed higher content of DM $(p<0.05)$, however, drying in the foliage did not influence the protein content, which was lower in the fruit $(p<0.05)$. Also, the highest percentage of WSC was quantified in the fruit $(p<0.05)$, as well as a WAS/PC ratio more favorable (Table I).

Table I. DM, CP, WSC content and WSC/CP ratio of fresh and foliage pre-wilted and fruit of noni, as indicators of their fermentative potential.

\begin{tabular}{llllll}
\hline \multirow{2}{*}{ Foliage } & \multicolumn{1}{c}{ DM } & CP & WSC & WSC/CP \\
& & $\mathbf{g ~ k g}^{-1}$ & \multicolumn{2}{c}{$\mathbf{g ~ k g}^{-1} \mathbf{~ D M ~}$} & \\
\cline { 2 - 6 } & Fresh & $246.7^{\mathrm{b}}$ & $185.5^{\mathrm{a}}$ & $34.3^{\mathrm{c}}$ & $0.18^{\mathrm{c}}$ \\
\cline { 2 - 6 } Fruit & Pre-wilted & $359.8^{\mathrm{a}}$ & $189.5^{\mathrm{a}}$ & $44.6^{\mathrm{b}}$ & $0.23^{\mathrm{b}}$ \\
\cline { 2 - 6 } & Fresh & $126.9^{\mathrm{c}}$ & $134.2^{\mathrm{b}}$ & $62.7^{\mathrm{a}}$ & $0.46^{\mathrm{a}}$ \\
\cline { 2 - 6 } & SEM \pm & 0.279 & 0.274 & 0.133 & 0.014 \\
\hline
\end{tabular}




\begin{tabular}{lcccc}
\hline Vegetal material (1) & $<0.001$ & 0.030 & $<0.001$ & $<0.001$ \\
\hline Pre-wilted (2) & $<0.001$ & $<0.001$ & $<0.001$ & $<0.001$ \\
\hline $1 \times 2$ & $<0.001$ & 0.229 & $<0.001$ & 0.001 \\
\hline
\end{tabular}

${ }^{a, b, c}$ Means with different superscripts within in the same column, differ significantly $(P<0.05)$ according to Duncan's multiple range test.

In this sense, the pre-wilted foliage increased the DM content in all cases, although there was a tendency to decrease to a higher inclusion of fruit. However, fresh foliage in same inclusion of fruit has more CP concentration than pre-wilted foliage, although they were similar in the proportions of 50:50 foliage (Fresh and pre-wilted): fruit (Figure 3).

The use of pre-wilted foliage with inclusions of fruit had a higher NDF content when compared to fresh foliage, mainly with $10 \%$ fruit with $345 \mathrm{~g} \mathrm{~kg}^{-1}$, although only up to $40 \%$ of fruit that decreased gradually. Likewise, a similar trend was observed for the contents of $A D F$ and $A D L$ in the mixtures, which had a higher content with $20 \%\left(259.81 \mathrm{~g} \mathrm{~kg}^{-1}\right)$ and $10 \%\left(128.73 \mathrm{~g} \mathrm{~kg}^{-1}\right)$ of fruit, respectively and a decrease in its fibrous content from $30 \%$ fruit (Figure 3 ).
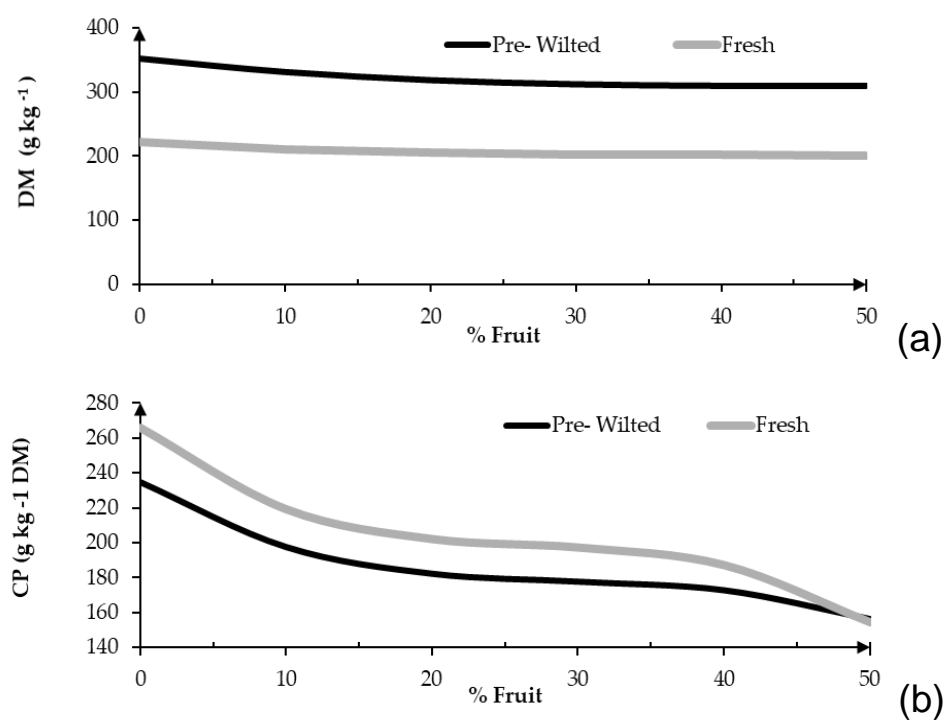


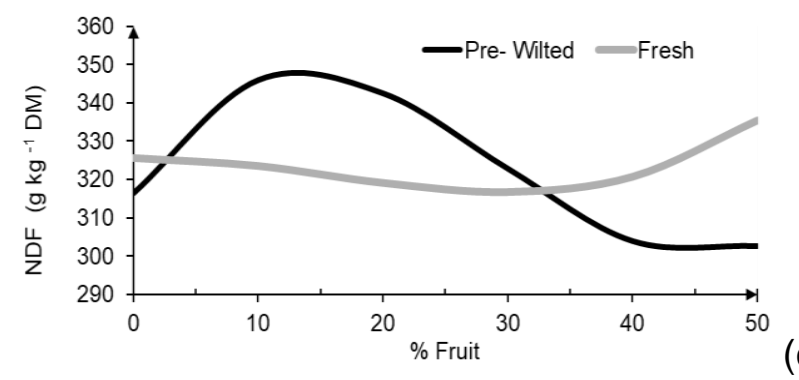

(c)
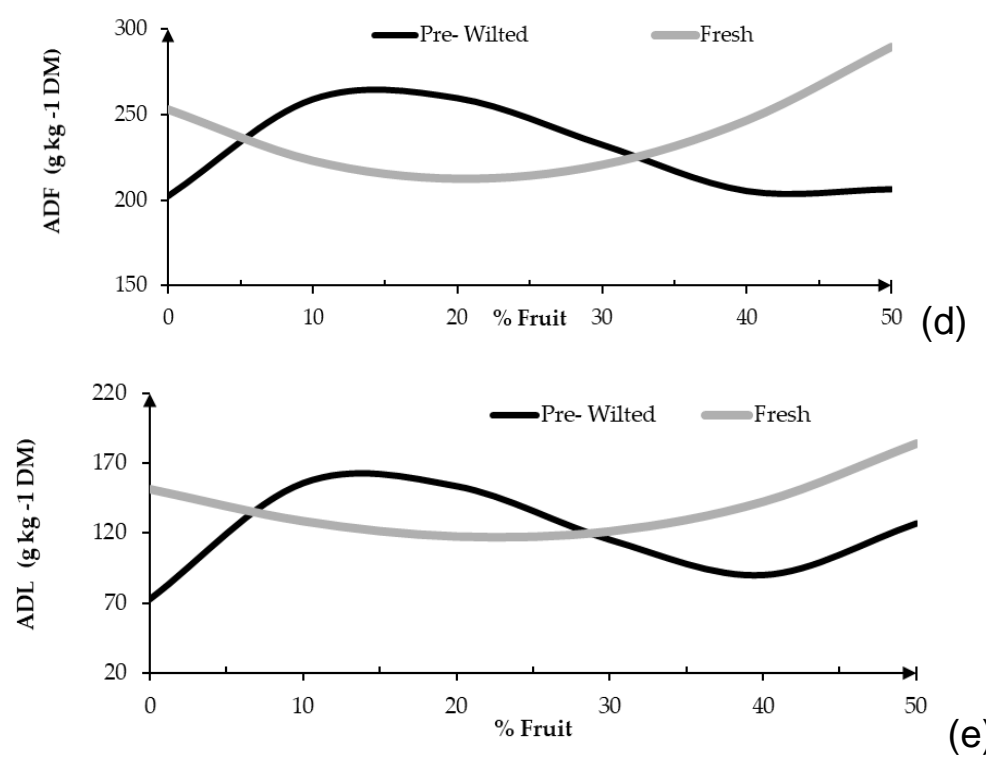

Figure 3. DM (a), CP (b), NDF (c), ADF (d) and ADL (e) contents of the silages made with different mixtures of noni (Morinda citrifolia L.).

Table II shows the functional relationship between fruit proportions versus the fermentative process parameters at 21 days. All the variables in the study were adjusted using a cubic model, mainly the $\mathrm{NH}_{3}-\mathrm{N} \mathrm{Nt}^{-1}$ in the fresh foliage with a high $\mathrm{R}^{2}$.

Table II. Model $a+b^{*}$ Fruit $+c^{\star} F r_{i t}{ }^{2}+d^{*}$ Fruit ${ }^{3}$ quantifying the response from some fermentative process parameters to the different fruit levels evaluated in the fresh and pre-wilted foliage.

\begin{tabular}{|c|c|c|c|c|c|c|c|c|c|c|}
\hline \multirow{3}{*}{ Variables } & \multicolumn{9}{|c|}{ Coefficients of cubic model } & \multirow{3}{*}{$\mathrm{R}^{2}$} \\
\hline & \multicolumn{3}{|c|}{ a } & \multicolumn{2}{|l|}{$b$} & \multicolumn{2}{|l|}{ c } & \multicolumn{2}{|l|}{$d$} & \\
\hline & & ate & SEM \pm & Estimate & SEM \pm & Estimate & SEM \pm & Estimate & SEM \pm & \\
\hline \multirow[t]{2}{*}{$\mathrm{pH}$} & $\mathrm{F}$ & 4.424 & 0.024 & -0.021 & 0.005 & 0.0007 & 0.0002 & 0.000007 & 0.00001 & 0.76 \\
\hline & W & 4.590 & 0.022 & -0.022 & 0.004 & 0.0009 & 0.0002 & -0.00001 & 0.00003 & 0.75 \\
\hline
\end{tabular}


Ensilability and chemical composition of silages made with different mixtures of noni (Morinda citrifolia L.)

\begin{tabular}{lllllllllll}
$\mathrm{NH}_{3}-\mathrm{N} \mathrm{Nt}^{-1}$ & $\mathrm{~F}$ & 10.35 & 0.184 & -0.177 & 0.036 & 0.0033 & 0.0018 & -0.00002 & 0.00002 & 0.90 \\
& $\mathrm{~W}$ & 6.548 & 0.131 & -0.132 & 0.025 & 0.0046 & 0.0013 & -0.00005 & 0.00002 & 0.75 \\
\hline
\end{tabular}

F: Fresh foliage; W: Wilted foliage.

Moreover, the functional relationship between fruit proportions versus chemical composition at 21 days are presented in Table III. The pre-wilted foliage showed a higher $\mathrm{R}^{2}$ for DM, NDF, ADF, ADL and cellulose, while CP and hemicelluloses were higher in the fresh plant material according the using a cubic model.

Table III. Model $a+b^{*}$ Fruit $+c^{\star}$ Fruit ${ }^{2}+d^{\star}$ Fruit ${ }^{3}$ quantifying the response from some nutrients to the different fruit levels evaluated in the fresh and pre-wilted silage.

\begin{tabular}{|c|c|c|c|c|c|c|c|c|c|c|}
\hline & & \multicolumn{8}{|c|}{ Coefficients of cubic model } & \multirow{3}{*}{$\mathrm{R}^{2}$} \\
\hline \multicolumn{2}{|c|}{ Nutrients } & \multicolumn{2}{|c|}{ a } & \multicolumn{2}{|c|}{ b } & \multicolumn{2}{|c|}{ c } & \multicolumn{2}{|c|}{$d$} & \\
\hline & & Estimate & SEM \pm & Estimate & SEM \pm & Estimate & SEM \pm & Estimate & SEM \pm & \\
\hline \multirow[t]{2}{*}{ DM } & $\mathrm{F}$ & 222.1 & 0.259 & -0.153 & 0.050 & 0.0041 & 0.002 & -0.00004 & 0.00003 & 0.85 \\
\hline & W & 352.2 & 0.394 & -0.283 & 0.077 & 0.0060 & 0.004 & -0.00006 & 0.00005 & 0.93 \\
\hline \multirow[t]{2}{*}{$\mathrm{CP}$} & $\mathrm{F}$ & 266.1 & 0.908 & -0.673 & 0.176 & 0.023 & 0.009 & -0.00030 & 0.00011 & 0.91 \\
\hline & W & 234.8 & 1.158 & -0.517 & 0.225 & 0.016 & 0.011 & -0.00020 & 0.00015 & 0.76 \\
\hline \multirow[t]{2}{*}{ NDF } & $\mathrm{F}$ & 325.6 & 0.617 & 0.005 & 0.119 & -0.003 & 0.006 & 0.00007 & 0.00008 & 0.41 \\
\hline & W & 316.3 & 1.236 & 0.516 & 0.240 & -0.025 & 0.012 & 0.00028 & 0.00015 & 0.60 \\
\hline \multirow[t]{2}{*}{ ADF } & $\mathrm{F}$ & 253.1 & 0.963 & -0.398 & 0.187 & 0.010 & 0.009 & -0.00001 & 0.00001 & 0.84 \\
\hline & W & 202.4 & 0.716 & 0.940 & 0.139 & -0.042 & 0.006 & 0.00047 & 0.00009 & 0.89 \\
\hline \multirow[t]{2}{*}{$A D L$} & $\mathrm{~F}$ & 151.4 & 1.191 & -0.276 & 0.230 & 0.004 & 0.011 & 0.00005 & 0.00015 & 0.72 \\
\hline & W & 72.65 & 0.562 & 1.417 & 0.109 & -0.067 & 0.005 & 0.00080 & 0.00007 & 0.98 \\
\hline \multirow[t]{2}{*}{ Cellulose } & $\mathrm{F}$ & 101.6 & 0.744 & -0.122 & 0.145 & 0.056 & 0.007 & -0.00060 & 0.00009 & 0.18 \\
\hline & W & 129.7 & 0.561 & -0.476 & 0.109 & 0.024 & 0.005 & -0.00030 & 0.00007 & 0.84 \\
\hline \multirow[t]{2}{*}{ Hem } & $\mathrm{F}$ & 72.53 & 0.726 & 0.403 & 0.141 & -0.013 & 0.007 & 0.00008 & 0.00009 & 0.85 \\
\hline & W & 113.9 & 1.197 & -0.424 & 0.232 & 0.017 & 0.011 & -0.00020 & 0.00015 & 0.34 \\
\hline
\end{tabular}

F: Fresh foliage; W: Wilted foliage.

A functional relationship was found between fruit proportions versus the fermentative process parameters and nutritional composition (Tables II and III), these results allow to predict the fermentative potential and the chemical composition of the silages made with fresh and pre-wilted foliage and fruit levels up to $50 \%$ of the proportion; as previously reported the pre-wilted positively 
influences the fermentation process, since the value of $R^{2}$ were mostly high, which ensured a good fit of the mathematical model, achieving good parameters of quality and the process fermentative, with a nutritional high value (Table III). Finally, our results suggest a direct relationship of noni fruit levels and pre-wilted on the quality fermentative and the chemical composition of the mixed silage of noni.

\section{Discussion}

The use of noni fruit exerted a rapid decrease in the $\mathrm{pH}$ values, mainly when the fruit levels in the mixture are increased compared with the pure forages (Figure 1). The biological rapid fermentation indicated a high potential acidity of noni fruit, which is favorable for a natural conservation process. Probably due to the content of water soluble carbohydrates (Table I), citric acid and other organic acids in the fruit, which increase with the maturation state. Other authors have reported a similar effect on silages made with different mixtures of orange fruit wastes and Leucaena foliage (Revuelta et al., 2008).

The variation of $\mathrm{NH} 3-\mathrm{N} \mathrm{Nt}^{-1}$ is an indicator of proteolysis processes. It is clear the decrease of protein destruction when fruit levels were augmented in the mixture (Figure 2b). After that, a $20 \%$ decrease or stabilization the protein destruction was observed. The lowest values in $\mathrm{NH}_{3}$ were obtained in wilted silages (from 6.54 to $5.55 \%$ ), which can be considered excellent, because showed an ammonia-nitrogen concentration of up to 8\% (Pineda et al., 2016) (Figure 2).

The ammonia concentrations must not be higher than $110-120 \mathrm{~g} \mathrm{~kg}^{-1}$ of total nitrogen, in well-preserved silages (Boschini \& Pineda, 2016). Pitt et al. (1985) showed mathematical models on the influence of the $\mathrm{pH}$ and nitrogen content on the proteolysis. This could have happened in this study, because when increased 
the fruit levels in the mixture was observed a decrease of CP (Figure 3b). Although there was an increase of the $\mathrm{pH}$ levels, Rolz et al. (2010) reports a decrease of $\mathrm{NH}_{3}$, when higher level of coffee pulp was added to the mixture, besides the positive influence of the pre-wilted in the silage process.

On the other hand, Zambello et al. (2004) have reported a minimum DM concentration range from 250 to $270 \mathrm{~g} \mathrm{~kg}^{-1}$ for plant materials to silage, which demonstrates that the DM concentration interfere directly in the fermentation process within the silo. In this sense, Boschini \& Pineda (2016) have reported that the optimal values to obtain good silage are between 330 and $370 \mathrm{~g} \mathrm{~kg}^{-1}$. In this sense, the DM ranges between 303.9 and $352.2 \mathrm{~g} \mathrm{~kg}^{-1}$ in the silages where the material was pre-wilted, and between 200.3 and $222.1 \mathrm{~g} \mathrm{~kg}^{-1}$ in the silages without previous drying (Figure 3a). All the treatments showed a tendency to decrease when the fruit levels were increased in the mixture (Figure 3), mainly by the humidity levels of the material. Nevertheless, all the values that were obtained in the silages with the material pre-wilted are considered of silage of good quality ( $\geq 30 \%$ of DM) (Ozkul et al., 2011).

The decrease of the protein when the fruits were incorporated in the silages (Figure 3b), could be attributed to the degradation of this nutrient during silage, due to a high concentration of non-protein nitrogen (Salem et al., 2013). As shown the WSC is majority in the fruit (Table I), this could provoke a higher buffering capacity in the foliage, which could be lowered when mixed with fruit (Wang et al., 2015). It is observed that the pre-drying process increases the contents of all variables measured in the fruits and foliage (except the $\mathrm{CP}$ ). It is necessary to highlight that the WSC/CP rate improves with the pre-drying. Apparently, the fermentation process and the chemical composition of the noni mixtures will depend on the plant material and the foliage drying process according to table I. 
There is a highly significant relationship $(p<0.05)$ between these two factors for the chemical composition, with the exception of the protein content.

Moreover, the changes in CP of the fruit may are related with the fermentation processes that happen during the drying of rich materials in WSC (Potterat \& Hamburger, 2007). There is a clear decrease of the $\mathrm{pH}$ in the mixtures (Figure 2a) compared to pure silages ( $0 \%$ fruit), meanwhile, all the $\mathrm{pH}$ values obtained with the fresh materials were significantly lower (from 4.18 to 4.25 ) than wilted silages (from 4.38 to 4.42 ). The $\mathrm{pH}$ is associated directly with the content of DM; a high DM provokes an appropriate fermentation by the levels of lactic acid. Likewise, the physiologic dryness limits the quantity of its synthesis and inhibits the development of the microorganisms, obtaining levels of $\mathrm{pH}$ above 4.2 (Wang et al., 2015)

The fibrous components such as NDF, FAD and LAD (Figure 3) in the pre-wilted silage present an increase until a point $\left(120 \mathrm{~g} \mathrm{~kg}^{-1}\right)$ starting from which begins a decrease of the same one. The opposite happens in the fresh silage, where it presents a decrease $\left(200 \mathrm{~g} \mathrm{~kg}^{-1}\right)$ and stops, then increases the values of the fibrous fraction, possibly as effect of the acidic and enzymatic hydrolysis of the hemicellulose, because the enzymes of the vegetable cells and microorganisms present in the fermentation process can break the cellular structures, breaking the chemical links of structural carbohydrates, mainly the cellulose (Zhao et al., 2016). This is very convenient for feeding non-ruminant animals such as pig and poultry, which do not assimilate ingredients with high levels of fiber (Jha \& Berrocoso, 2016). 


\section{Conclusions}

Results from the present study indicated that fruit levels in a proportion of $30 \%$ in the mixture and pre-wilted process of the foliage improved the fermentation process and chemical composition (Except to $\mathrm{CP}$ ) of the silage noni foliage.

Thus, the increase in the level of fruit increased the concentration of WSC and the ratio of WSC/PC. Moreover, the pre-wilted foliage increased the concentration of nutrients and its combination with fruit levels decreased the fibrous compounds and CP concentration in the silage. Likewise, a high statistical significance was found between the interaction of the factors, the material of the plant and the pre-drying for DM and WSC, except for CP.

Also, all the variables in the study were adjusted using the cubic models, with high values the $\mathrm{R}^{2}$, as much for the fresh silages as for the pre-wilted. In this sense, the pre-wilted foliage and fruit proportions showed a high dependence between the variables, such as NDF, ADF, ADL and cellulose, while CP and hemicelluloses were higher in the fresh plant material. It is recommended in vivo studies of the best silages as animal feed, preferably in non-ruminant animals.

\section{References}

Ali, M., Kenganora, M., \& Manjula S. N. (2016). Health benefits of Morinda citrifolia (Noni): A review. Pharmacognosy Journal, 8(4): 321-334. DOI: https://doi.org/10.5530/pj.2016.4.4.

Amer, S., Hassanat, F., Berthiaume, R., Seguin, P., \& Mustafa A. F. (2012). Effects of water soluble carbohydrate content on ensiling characteristics, chemical composition and in vitro gas production of forage millet and forage sorghum silages. Animal Feed Science and Technology, 177(1-2): 23-29. DOI: https://doi.org/10.1016/j.anifeedsci.2012.07.024.

Arunachalam, V. (2018). Morinda citrifolia L. (Rubiaceae): a multi-purpose tree for coastal ecosystems and its variability in Konkan region of India. Genetic Resources and Crop Evolution, 65(6): 1751-1765. DOI: https://doi.org/10.1007/s10722-018-0642-5.

Borreani, G., Tabacco, E., Schmidt, R. J., Holmes, B. J., \& Muck R. E. (2018). Silage review: Factors affecting dry matter and quality losses in silages. Journal of Dairy Science, 101(5): 3952-3979. DOI: https://doi.org/10.3168/ids.201713837.

Boschini, C., \& Pineda, L. (2016). Kikuyu (Pennisetum clandestinun or Kikuyuocloa clandestina) silage fermented with three additives. Agronomía Mesoamericana, 27(1):49-60. DOI https://doi.org/10.15517/AM.V2711.21895. Ciencia y Agricultura (Cien. Agri.) Vol. 16 (1). L-ISSN 0122-8420. eISSN 2539-0899. Enero-Abril 2019, pp. 3-16. Tunja (Boyacá) - Colombia. DOI: https://doi.org/10.19053/01228420.v16.n1.2019.8802 
Canibe, N., \& Jensen, B. B. (2011). Fermented liquid feed-microbial and nutritional aspects and impact on enteric diseases

in pigs. Animal Feed Science and Technology, 173 (1-2): 17-40. DOI:

https://doi.org/10.1016/j.anifeedsci.2011.12.021.

Conway, E. (1947). Microdiffusion analysis and volumetric error. London, England: Crosby Lockwood and Son Ltd.

Grant, R. J., \& Ferraretto, L. F. (2018). Silage review: Silage feeding management: Silage characteristics and dairy cow feeding behavior. Journal of Dairy Science, 101(5): 4111-4121. DOI: https://doi.org/10.3168/ids.2017-13729.

Hernández, A., Pérez, J. M., \& Boch, D. (1991). Nueva versión de la clasificación genética de los suelos de Cuba. Ciudad de La Habana, Cuba: AGROINFIR-MINAG.

Jha, R., \& Berrocoso, J. F. (2016). Dietary fiber and protein fermentation in the intestine of swine and their interactive effects on gut health and on the environment: A review. Animal Feed Science and Technology, 212 (2): 18-26. DOI: https://doi.org/10.1016/j.anifeedsci.2015.12.002.

Ke, W. C., Yang, F. Y., Undersander, D. J., \& Guo, X. S. (2015). Fermentation characteristics, aerobic stability, proteolysis and lipid composition of alfalfa silage ensiled with apple or grape pomace. Animal Feed Science Technology, 202(4): 12-19. DOI: https://doi.org/10.1016/i.anifeedsci.2015.01.009.

Kung, L., Shaver, R. D., Grant, R. J., \& Schmidt, R. J. (2018). Silage review: Interpretation of chemical, microbial, and organoleptic components of silages. Journal of Dairy Science, 101(5): 4020-4033. DOI: https://doi.org/10.3168/jds.2017-13909.

Martínez, Y., Carrión, Y., Rodríguez, R., Valdivié, M., Olmo, C., Betancur, C., Liu, G., Al-Dhabi, N., \& Duraipandiyan, V. (2015). Growth Performance, organ weights and some blood parameters of replacement laying pullets fed with increasing levels of wheat bran. Revista Brasileña de Ciência Avícola, 17(3): 347-354. DOI: http://doi.org/10.1590/1516-635X1703347-354.

Official Methods of Analysis of International (AOAC). 18 ${ }^{\text {th }}$ ed. (2011). Maryland, USA: AOAC International.

Ozkul, H., Kilic, A., \& Polat, M. (2011). Evaluation of mixtures of certain market wastes as silage. Asian-Australasia Journal of Animal Science, 24(9): 1243-1248. DOI: https://doi.org/10.5713/ajas.2011.10460.

Pieper, B., Hoedtke, S., Wensch, D. M., Korn, U., Wolf, P., \& Zeyner, A. (2017) Validation of the Rostock fermentation test as an in vitro method to estimate ensilability of forages using glass jar model silages as a basis for comparison. Grass Forage Science, 72(3): 568-580. DOI: https://doi.org/10.1111/gfs.12259.

Pineda, L., Chacón, P., \& Boschini, C. (2016). Evaluation of African star grass (Cynodon nlemfluensis) silage quality when mixed with three different additives. Agronomía Costarricense, 40(1): 11-27.

Pitt, R. E., Muck, R. E., \& Leibensperger, R. Y. (1985). A quantitative model of the ensilage process in lactate silages. Grass Forage Science, 40(3): 279-303. DOI: https://doi.org/10.1111/j.1365-2494.1985.tb01755.x.

Potterat, O., \& Hamburger, M. (2007). Morinda citrifolia (Noni) fruit-phytochemistry, pharmacology, safety. Planta Medica, 73(3):191-199. DOI: https://doi.org/10.1055/s-2007-967115.

Revuelta, D., Mosquera, D., \& Cuba, F. (2008). Ensiling potential of orange fruit wastes (Citrus sinensis). Revista Ciencias Técnicas Agropecuarias, 17(2): 41-44.

Rivera, A., Cedillo, L., Hernández, F., Castillo, V., Sánchez, A., \& Castañeda, D. (2012). Bioactive constituents in ethanolic extract leaves and fruit juice of Morinda citrifolia. Annals of Biological Research, 3(2): 1044-1049.

Rolz, C., De Leon, R., Cifuentes, R., \& Porres, C. (2010). Windrow composting of sugarcane and coffee byproducts. Sugar Technology, 12(1): 15-20. DOI: https://doi.org/10.1007/s12355-010-0004-x.

Rosalizan, M. S., Rohani, M. Y., \& Khatijah, I. (2010). Physico-chemical characteristics of Morinda citrifolia fruit during growth and maturation. Journal of Tropical Agriculture and Food Science, 38: 21-30.

Sakarkar, D. M., \& Deshmukh, V. N. (2011). Ethnopharmacological review of traditional medicinal plants for anticancer activity. International Journal of Pharm Tech Research, 3(1): 298-308.

Ciencia y Agricultura (Cien. Agri.) Vol. 16 (1). L-ISSN 0122-8420. eISSN 2539-0899.

Enero-Abril 2019, pp. 3-16. Tunja (Boyacá) - Colombia. DOI:

https://doi.org/10.19053/01228420.v16.n1.2019.8802 
Ensilability and chemical composition of silages made with different mixtures of noni (Morinda citrifolia L.)

Salem, A. Z., Zhou, C. S., Tan, Z. L., Mellado, M., Salaza, C., Elghandopur, M. M., \& Odongo, N. E. (2013). In vitro ruminal gas production kinetics of four fodder trees ensiled with or without molasses and urea. Journal of Integrative Agriculture, 12(7): 1234-124. DOI: https://doi.org/10.1016/S2095-3119(13)60438-4.

Sang, S., Cheng, X., Stark, R. E., Badmaev, V., Ghai, G., Rosen, R. T., \& Ho, C. T. (2001). Flavonol glycosides and novel iridoid glycoside from the leaves of Morinda citrifolia. Journal of Agricultural and Food Chemistry, 49(9):44784481.DOI: https://doi.org/10.1021/jf010492e.

Santana, A., Cisneros, M., Martínez, Y., \& Pascual, Y. (2015). Conservation and chemical composition of Leucaena leucocephala plus fresh or wilted Pennisetum purpureum mixed silages. Revista MVZ Córdoba, 20(1): 4895-4906. DOI: https://doi.org/10.21897/rmvz.5.

Santana, A., Pérez, A., \& Figueredo, M. E. (2010) Optimal harvest age for napier grass (Pennisetum purpureum Schum.) during the rainy season based on yield and nutritional value. Revista Técnica Pecuaria, 1(3): 277-286.

Van Soest, P. J., Robertson, J. B., \& Lewis, B. A. (1991). Methods for dietary fiber, neutral detergent fiber, and non-starch polysaccharides in relation to animal nutrition. Journal of Dairy Science, 74: 3583-3597. DOI: https://doi.org/10.3168/jds.S0022-0302(91)78551-2.

Vandermeulen, S., Ramírez, C. A., Beckers, Y., Claessens, H., \& Bindelle, J. (2018). Agroforestry for ruminants: a review of trees and shrubs as fodder in silvopastoral temperate and tropical production systems. Animal Production Science, 58(5): 767-777. DOI: https://doi.org/10.1071/AN16434.

Wang, X., Chen, Q., Bi, J., Gao, K., Zhou, L., Wu, X., \& Lü, J. (2015). Effect of hot air-pulsed sudden decompression flashing drying on moisture and microstructure in apple slices. Transactions of the Chinese Society of Agricultural Engineering, 31(20): 287-293.

Weissbach, F., \& Berg, K. (1977). Studies on the complete determination of the dry matter content of silages: 2. Communication: Methods for the determination and correction of the dry matter content. Archives of Animal Nutrition, 27: 69-84.

Wiseman, H. G., \& Irvin, H. M. (1957). Silage analysis, determination of organic acids in silage. Journal of Agricultural and Food Chemistry, 5(3): 213-215. DOI: https://doi.org/10.1021/if60073a007.

Zambello, E., Costa, C., De Beni, M., Silveira, A. C., Padovani, C. R., \& Zambello, S. (2004). Fermentation and nutritive value of silage and hay made from the aerial part of cassava (Manihot esculenta Crantz). Scientia Agricola, 61(4): 364-370. DOI: http://dx.doi.org/10.1590/S0103-90162004000400003.

Zhao, L., Ren, L., Zhou, Z., Meng, Q., Huo, Y., \& Wang, F. (2016). Improving ruminal degradability and energetic values of bamboo shoot shell using chemical treatments. Animal Science Journal, 87(7): 896-903. DOI: https://doi.org/10.1111/asj.12512. 